\title{
INDÚSTRIA BIOFARMACÊUTICA E SEU PROCESSO PRODUTIVO
}

\author{
Albrecht I*, Rhoden SA ${ }^{* *}$ Pamphile JA**
}

Resumo

\begin{abstract}
A biotecnologia aplicada na produção de medicamentos vem se tornando uma área economicamente estratégica dentro das grandes indústrias farmacêuticas. Medicamentos biológicos ou biofármacos são substâncias que interagem com proteínas humanas e são produzidos a partir de micro-organismos, tecidos de origem animal ou vegetal, ou cultura de células modificadas geneticamente. São alguns exemplos os antibióticos, vacinas, hormônios, fatores sanguíneos, anticorpos monoclonais, entre outros. O processo produtivo destes apresenta peculiaridades, sendo composto por etapas como cultura de células hospedeiras, fermentação, extração, purificação, isolamento e esterilização. Este artigo sumariza os principais processos envolvidos na produção de medicamentos biológicos ou derivados de biotecnologia. Palavras-chave: Biofármacos. Indústria biofarmacêutica. Processo produtivo.
\end{abstract}

\section{Biopharmaceutical industry and its production process}

\begin{abstract}
Biotechnology applied in the production of drugs is becoming an economically strategic area within large pharmaceutical companies. Drugs are biological or biopharmaceutical substances that interact with human

\footnotetext{
* Mestre em Ciências Farmacêuticas pela Universidade Estadual Paulista; Especialista em Biotecnologia pela Universidade Estadual de Maringá; Farmacêutica Industrial pela Universidade Estadual de Maringá; Avenida Cardeal Motta, 430, City América 05101-210 São Paulo, São Paulo, Brasil; albrecht.ingrid@hotmail.com

** Doutor e Mestre em Biologia Comparada pela Universidade Estadual de Maringá; Professor do Instituto Federal Catarinense de São Francisco do Sul; sandro_ar@hotmail.com

${ }^{* * *}$ Doutor Sandwiche pela Universite de Paris XI; Doutor em Genética e Melhoramento de Plantas pela Escola Superior de Agricultura Luiz de Queiroz; Professor do Departamento de Biotecnologia, Genética e Biologia Celular da Universidade Estadual de Maringá; japamphile@uem.br
} 
proteins and are produced from microorganisms, tissues of animal or vegetable origin, or cultivation of genetically modified cells. Some examples are antibiotics, vaccines, hormones, blood factors, monoclonal antibodies, and others. The production process of these presents peculiarities, comprising steps as host cell culture, fermentation, extraction, purification, isolation and sterilization. This article summarizes the main processes involved in the production of biological products or derived from biotechnology. Keywords: Biopharmaceuticals. Biopharmaceutical industry. Production process.

\section{INTRODUÇÃO}

Dos aproximados 30.000 genes componentes do genoma humano, é estimado que apenas 10\% expressam proteínas adequadas para a modulação da via clássica, combinado a genes que podem ser relevantes em doenças, cerca de 600 são viáveis como drogas alvo em humanos. ${ }^{1}$

A biotecnologia se converteu na fonte mais importante de novos medicamentos e também em um setor estratégico economicamente. Por isso, a indústria farmacêutica investe milhões de dólares cada ano na pesquisa de novos medicamentos. ${ }^{2}$

Segundo Ferro, ${ }^{3}$ na área da saúde, a biotecnologia tem sido aplicada para o desenvolvimento de vacinas, terapia gênica e celular, além de para o desenvolvimento e uso de células-tronco embrionárias. Outra aplicação da biotecnologia é o desenvolvimento e a produção de medicamentos biológicos ou derivados de processos biotecnológicos. ${ }^{2}$

Formas biofarmacêuticas apresentam várias vantagens como provisão de tratamento efetivo em doenças crônicas e incomuns. Drogas recombinantes oferecem segurança e efeitos colaterais reduzidos, podendo ser produzidas em larga escala por processos biotecnológicos. ${ }^{4}$ Os biofármacos representam um segmento de rápido crescimento na indústria farmacêutica. ${ }^{5}$

Segundo Roche, ${ }^{2}$ os medicamentos biológicos ou biofármacos são substâncias terapêuticas homólogas ou que interagem com proteínas humanas. Sua estrutura molecular é extremamente complexa e o componente ativo é heterogêneo, sendo de difícil caracterização e replicação.

Os biofármacos são produzidos utilizando matéria-prima de origem biológica, obtidos por meio de microorganismos, órgãos e tecidos de origem vegetal ou animal, células ou fluidos de origem humana ou animal; ou biotecnológica, obtidos por meio de células modificadas geneticamente. São exemplos de biofármacos: antibióticos, citocinas, enzimas, fatores sanguíneos, agentes tromboembolíticos ativadores dos tecidos plasminogênios, hormônios como a insulina, fatores de crescimento hematopoiéticos, interferons $\alpha, \beta$ e $\gamma$, vacinas e anticorpos monoclonais. ${ }^{4,2}$

Existem grandes diferenças no processo de produção, avaliação e monitoramento de biofármacos. ${ }^{2}$ Nesta revisão são destacadas algumas das etapas envolvidas no processo produtivo de medicamentos biológicos ou derivados de processos biotecnológicos. 


\section{PROCESSO PRODUTIVO DE BIOFÁRMACOS}

Segundo Almeida et al., os atuais processos biotecnológicos de produção de medicamentos envolvem essencialmente cinco diferentes grupos de organismos: bactérias, fungos, plantas, insetos e células de mamíferos, como, por exemplo, animais transgênicos e células de hamsters. Para isso, algumas técnicas como a mutagênese, a fermentação, os processos sexuais, as técnicas de DNA recombinante e hibridoma são usadas.

Como exemplo, antibióticos são produzidos por fermentação e síntese envolvendo microorganismos. Fatores sanguíneos e enzimas são produzidos por técnicas recombinantes em células ovarianas de hamster chinês (células $\mathrm{CHO}$ ), hormônios, citocinas e interferons, por técnica de DNA recombinante em bactérias Escherichia coli. Vacinas, como a vacina contra hepatite A e B, são produzidas por técnicas de DNA recombinante em células humanas e em células de fungos Saccharomyces cerevisiae; ou por fermentação de bactérias Clostridium botulinum tipo B, como a vacina botulínica tipo B. ${ }^{4}$

A escolha de grande número de produções de proteínas por técnicas recombinantes depende das modificações pós-traducionais requeridas. As produções de proteínas em E. coli apresentam uma série de vantagens: fácil manuseio, necessidade de fermentação simples e curto tempo de geração. A levedura S. cerevisiae também apresenta benefícios: rápido crescimento, alta densidade de células, além de ser seguro, pois não é pirogênico nem patogênico. Entretanto, carecem de maquinário para produzir modificações pós-traducionais como $\mathrm{N}$ e O-glicosilação, acilação de ácidos graxos, fosforilação e formação de pontes dissulfeto, as quais são requeridas para a adequada montagem e funcionalidade das proteínas. ${ }^{5}$

Segundo Martinez et al., ${ }^{6}$ a glicosilação de proteínas realizadas por leveduras podem diferir das realizadas pelas células de mamíferos. A N-glicosilação em leveduras, por exemplo, é do tipo manose, enquanto a N-glicosilação em humanos é, principalmente, do tipo híbrido ou complexo. Experimentos muito promissores têm recentemente introduzido padrões de glicosilação humana em leveduras. A engenharia genética e metabólica pode atuar em S. cerevisiae, resultando em gerações de linhagens com maior capacidade de produção de proteínas heterólogas.

No caso de proteínas mais simples, como insulina e hormônio do crescimento, que não são glicosiladas, são produzidas em E. coli. Proteínas mais complexas, que requerem modificações póstraducionais, são produzidas em células de mamíferos. ${ }^{5}$

Várias espécies de mamíferos, como coelhos, suínos, ovelhas, cabras e vacas, são avaliadas e utilizadas na produção de proteínas recombinantes no leite desses animais. A geração de animais transgênicos pode ser conseguida dependendo da espécie, pela microinjeção de DNA em pronúcleos de embriões, usando vetores lentivirais. O uso de elementos genéticos móveis (transposons), a incubação de esperma com DNA seguido de fertilização in vitro, a transferência de genes externos em células pluripotentes, bem como a transferência de genes externos em células somáticas são outras formas de obtenção de animais transgênicos. ${ }^{7}$ 
Proteínas recombinantes também podem ser produzidas a partir da utilização de plantas, que variam de plantas inteiras crescendo no solo ou em células vegetais crescendo em suspensão com meio sintético em um biorreator. ${ }^{8}$

As principais dificuldades de se produzir prostaglandinas por biotecnologia estão sendo ultrapassadas pelo uso de enzimas de mamíferos de forma mais eficaz, otimizando os parâmetros físico-químicos, que incluem: temperatura, $\mathrm{pH}$, força iônica, concentração e tipo de substratos e produtos, cofatores enzimáticos e os parâmetros de bioengenharia, como o tipo de reator e a cinética de reação, agitação e aeração. ${ }^{9}$

\subsection{CULTURA DE CÉLULAS E FERMENTAÇÃO}

A organização de uma planta industrial de fermentação varia de uma empresa para outra, dependendo do que será produzido. A cultura de células geralmente vem de uma cultura da própria empresa, mas pode ser obtida de uma coleção de cultura pública ou ligada a uma patente. ${ }^{10}$

Segundo Närhi e Nordström, ${ }^{11}$ qualquer alteração no banco de células durante os estudos clínicos requer experimentos e documentações regulatórias adicionais. Por isso, atenção especial deve ser dispensada para a capacidade de a célula hospedeira produzir moléculas estáveis e em elevada expressão para permitir a viabilidade do processo produtivo em escala industrial.

As células hospedeiras podem ser cultivadas em tanques de fermentação ou em fermentadores com suporte de fibra oca. ${ }^{11}$ Os nutrientes que fazem parte do meio de cultura são compostos por diversas matérias-primas, algumas vezes, são anteriormente preparados ou modificados, incluindo sacarificação, como é o caso de carboidratos complexos como o amido ou a celulose. ${ }^{10}$

Um inóculo é, primeiramente, preparado a partir de liofilizado, cuja pureza deve ser verificada sobre uma placa e ágar. O organismo é, em seguida, cultivado em frascos com agitação em volumes crescentes até atingir cerca de $10 \%$ do volume fermentador de escala piloto. Então, é introduzido em um fermentador piloto antes de ser transferido para um fermentador industrial. ${ }^{10}$

$\mathrm{O}$ controle de qualidade deve ser realizado regularmente para garantir que o material adequado seja produzido. Esterilidade é importante em processos de microbiologia industrial, sendo mantida por vários meios, entre eles, o uso de vapor, a filtração ou por compostos químicos. Ar, água e vapor são utilidades que devem ser fornecidas e apropriadamente tratadas antes do uso. ${ }^{10}$

O uso de um meio de cultura adequado e industrialmente aplicável é importante para o desenvolvimento do micro-organismo na indústria. $\mathrm{O}$ meio líquido é, geralmente, empregado na indústria, pois ele requer menos espaço, é mais fácil de controlar em processos e elimina o custo de prover ágar e outros agentes sólidos. ${ }^{10}$

Segundo Okafor, ${ }^{10}$ todos os meios de cultura microbiológica devem satisfazer as necessidades do organismo em termos de carbono, nitrogênio, minerais, fatores de crescimento e água. Adicionalmente, não devem conter materiais que inibam o crescimento. É essencial realizar 
uma análise completa sobre o crescimento do organismo ao decidir qual a quantidade dos vários elementos que devem ser adicionados ao meio. Fatores como o tipo do bioreator usado e o modo de operação (batelada ou contínuo) também influenciam o crescimento dos micro-organismos. ${ }^{12}$ Para induzir ou aumentar a produção de metabólitos secundários em células de plantas, utiliza-se a estratégia de adição de compostos precursores ou intermediários ao meio de cultivo celular, ou a aplicação de estresse físico ou químico nas células em suspensão. ${ }^{13}$

Critérios como qualidade, custo e disponibilidade da matéria-prima, custos de transporte, facilidade de descarte de resíduos, adequada composição química do meio, presença de precursores relevantes e satisfação do crescimento e produção do micro-organismo são importantes para decidir qual matéria-prima deve ser usada em produções que gerem produtos a partir de determinados microorganismos. $^{10}$

Produtos obtidosindustrialmente pormeio de micro-organismos podem ser divididos naqueles que são do metabolismo primário, como enzimas e aminoácidos, ou do metabolismo secundário, como antibióticos, toxinas, pigmentos, alcaloides, entre outros. Além disso, a superprodução desses metabólitos pode ser modulada por meio de regulação enzimática e controle de permeabilidade pelos próprios micro-organismos. ${ }^{10}$

Segundo Okafor, ${ }^{10}$ fermentação é qualquer processo no qual micro-organismos são cultivados em larga escala, mesmo sem que seja em condições aeróbicas. O processo de fermentação ocorre em fermentadores ou biorreatores, os quais são reservatórios que fornecem aos micro-organismos condições ideais de temperatura, $\mathrm{pH}$ e oxigênio para seu crescimento e produção dos produtos desejados. Os fermentadores podem ser do tipo líquido, também conhecido como estado submerso, ou sólido, conhecido como de superfície, sendo o do tipo submerso o mais comum.

Aproximadamente $75 \%$ do volume total do fermentador são utilizados para a fermentação, o restante do volume é deixado para possíveis gases e espumas formados durante o processo. Existem vários tipos de fermentadores, os quais variam em forma, configuração, tipo de processo (contínuo ou descontínuo) e tipo de meio (aeróbico ou anaeróbico). Os fermentadores precisam pás ou impelidores para promover agitação e sistema de aquecimento, pois muitos processos de fermentação se processam em meios aquecidos. Parâmetros como controle de $\mathrm{pH}$, temperatura, pressão, oxigênio, gás carbônico e formação de espuma precisam ser monitorados para garantir as condições ideais para a produção dos produtos desejados. ${ }^{10}$

\subsection{EXTRAÇÃO}

Os processos biotecnológicos baseiam-se no crescimento e multiplicação de células, as quais produzem produtos de interesse que podem estar dentro ou fora das células. O produto desejado pode estar ligado ao micélio ou a células bacterianas, como no caso de enzimas ou antibióticos, se o produto estiver no interior das células, as paredes celulares precisam ser rompidas. As células podem 
ser rompidas por calor ou mecanicamente, e os restos celulares removidos por centrifugação ou filtração. Posteriormente, quando o material está disponível no meio extracelular, o produto precisa ser separado do meio de fermentação e do material celular, usualmente feito por meio de extração líquida, centrifugação ou filtração, seguido de purificação. ${ }^{10,14}$

Em fermentadores com suporte de fibra oca, a biomassa é separada do meio de cultura e as células não precisam ser colhidas. Produtos extracelulares são colhidos do meio de cultura, mas produtos intracelulares necessitam da ruptura das células hospedeiras. ${ }^{11}$

O rompimento celular precisa ser controlado para que não ocorra desnaturação dos produtos desejados. Entre os meios de ruptura de células estão os mecânicos - homogeneizadores, moinho de bolas e ultrassom - e os não mecânicos - permeabilização química, permeabilização mecânica ou choque osmótico e permeabilização enzimática. ${ }^{10}$

Em geral, a etapa inicial separa sólidos da fração líquida, removendo os sólidos insolúveis de forma a facilitar os passos posteriores. Na maioria dos casos, os métodos de separação usados são filtração, centrifugação, decantação e fracionamento de espuma. ${ }^{10}$ A extração também compete outros métodos de separação, como adsorção, precipitação, cromatografia, destilação, separação por membranas, troca iônica e eletrodiálise. ${ }^{15}$

O principal problema da recuperação de metabólitos por extração é a complexidade dos meios de cultura, o que significa que vários subprodutos também são extraídos junto ao produto desejado. Técnica de extração alternativa como extração reativa e extração em duas fases tem sido avaliada a fim de melhorar a seletividade do produto recuperado. ${ }^{15}$

A extração líquida é amplamente utilizada na indústria. É utilizada para transferir um soluto a partir de um solvente para outro no qual é mais solúvel. Também pode ser usada para separar os sólidos solúveis a partir da mistura com o material insolúvel por tratamento com um solvente. Nesse método, o caldo deve ser extraído com um solvente hidrofóbico e com agitação, deixa-se assentar e o solvente que deve conter o material a ser extraído é removido. ${ }^{10}$

Segundo Kragl, ${ }^{15}$ o processo de extração pode ser dividido em sistemas de duas fases e três fases e subdividido conforme o tipo de técnica de extração. No sistema de duas fases, os microorganismos são separados do meio de cultura por filtração ou centrifugação. O produto é extraído das células livres do meio de cultura por solventes, extração reativa, usando pareadores iônicos ou extração aquosa.

O sistema de três fases consiste em uma emulsão em membrana líquida, um suporte sólido em membrana líquida e um sistema de micela inversa. É usado para separação enantiomérica de enzimas imobilizadas. A extração sólida suportada por membrana líquida acontece quando se utilizam membranas de fibras ocas, sendo bastante usado para extração de aminoácidos. ${ }^{15}$

A extração por dissociação é um caso especial de extração líquido-líquido. Muitos dos produtos de fermentação são bases ou ácidos fracos. Quando se utiliza extração por solvente, o $\mathrm{pH}$ é escolhido de maneira que o material a ser isolado não esteja ionizado, pois a forma ionizada é 
mais solúvel na fase aquosa e a forma não ionizada mais solúvel na fase solvente. As bases fracas são, portanto, extraídas em condições de $\mathrm{pH}$ alto e os ácidos fracos em $\mathrm{pH}$ baixo. ${ }^{10}$

Entre os vários métodos, a filtração pode ser feita por filtro rotativo a vácuo, que consiste no uso de um cartucho cilíndrico no qual é possível adicionar elemento filtrante, como, por exemplo, terra diatomácea, e aplicada rotação e vácuo. ${ }^{10}$ Membranas também são frequentemente usadas para separar células na primeira fase de recuperação de produtos, embora não sejam muito seletivas e sejam prejudicadas pela incrustação de proteínas. ${ }^{15}$

Na indústria de isolamento de enzimas, a centrifugação é preferível à filtração, pois os detritos celulares indesejados são muito eficientemente removidos por esse método. ${ }^{10}$

A coagulação é a coesão dos coloides dispersos em pequenos flocos, e na floculação, esses flocos formam agregados maiores. O primeiro é induzido por eletrólitos e o último por polieletrólitos de elevado peso molecular, solúveis em água que podem ser obtidos em formas iônicas, aniônicas ou catiônicas. Bactérias e proteínas que são coloides com carga negativa são facilmente floculadas. Argila ou carvão ativado pode ser utilizado. ${ }^{10}$

\subsection{PURIFICAÇÃO}

Os métodos de purificação eliminam impurezas, deixando o produto desejado mais puro. ${ }^{10}$ Impurezas de um processo biofarmacêutico incluem contaminantes derivados do meio de cultura, das células hospedeiras ou de impurezas, como vírus e fungos, por exemplo. O processo de purificação pode ser realizado por cromatografia de filtração em gel, de troca iônica, de interação hidrofóbica ou por afinidade. ${ }^{11}$

A troca iônica e eletrodiálise são utilizadas para a separação de metabólitos primários de baixo peso molecular. ${ }^{15}$ Filtrados iônicos de caldos de fermentação podem ser concentrados e purificados utilizando resinas de trocas iônicas empacotadas em colunas. Uma resina de troca iônica é um polímero, normalmente poliestireno, com sítios carregados eletronicamente, em que um íon pode substituir outro. Embora existam vários grupos funcionais que possuem cargas, apenas alguns são usados em resinas de troca iônica sintéticas, como, por exemplo, o grupo-COOH, que é fracamente ionizado para - $\mathrm{COO}^{-}, \mathrm{SO}_{3} \mathrm{H}$, que é fortemente ionizada a $\mathrm{SO}_{3}^{-},-\mathrm{NH}_{2}$, que atrai fracamente prótons para formar $\mathrm{NH}_{3}$. A eficiência de troca iônica depende de fatores como capacidade da resina de adsorver os íons, área superficial, fluxo e temperatura de eluição. A estreptomicina, por exemplo, é extraída em resina com grupo ácido carboxílico. ${ }^{10}$

Segundo Kragl, ${ }^{15}$ apesar da sua baixa seletividade, a precipitação é utilizada como primeiro passo para a recuperação de diversos compostos. O processo de precipitação baseia-se na insolubilidade de alguns sais, sendo muito útil para a eliminação de impurezas proteicas ou no isolamento de enzimas. De acordo com Okafor, ${ }^{10}$ os sais são precipitados pela adição de sais inorgânicos ou pela redução da solubilidade com adição de solventes orgânicos, como o álcool no caso de enzimas. 
Na cromatografia, os componentes de uma mistura de solutos migram em taxas diferentes em um sólido, por causa da diferença de solubilidade dos solutos em um determinado solvente. A solução contendo a mistura de solutos é introduzida em uma extremidade da fase sólida e o solvente flui através do ponto inicial de aplicação. Produtos de fermentação podem ser separados por cromatografia de adsorção, de partição, de troca iônica ou de filtração em gel. ${ }^{10}$

De acordo com Kragl, ${ }^{15}$ a adsorção tem a desvantagem de ter baixa capacidade de carga, de modo que é aplicada se outras técnicas são menos eficazes. Alguns sólidos são capazes de adsorver e concentrar determinadas substâncias sobre as suas superfícies em contato com uma solução líquida ou mistura gasosa. Estes incluem carvão ativado, óxidos de silício, alumínio e titânio e vários tipos de argilas absorventes. $\mathrm{O}$ carvão ativado é usado para remover cor. ${ }^{10}$

A cristalização é o método de purificação final para os produtos que podem suportar o calor. A solução é concentrada por aquecimento e a evaporação à pressão atmosférica produz uma solução supersaturada. Em muitos produtos de fermentação, a remoção de água é feita por aquecimento à pressão reduzida ou por redução da temperatura e de modo a formar cristais, os quais podem ser centrifugados. Para se obterem cristais, primeiro uma solução supersaturada é produzida e os núcleos ou sementes são formados; então, as moléculas do soluto constroem os núcleos de cristalização. Partículas cristalinas a partir de uma preparação prévia podem ser introduzidas deliberadamente para a produção de núcleos. ${ }^{10}$

\subsection{ISOLAMENTO E SECAGEM}

O isolamento final ou polimento refere-se à última etapa da purificação, cujo resultado é um produto puro e homogêneo. ${ }^{10,16}$ É feito pela transformação de produtos cristalinos ou pela secagem do produto diretamente da solução. Os produtos cristalinos podem ser lavados e filtrados em camadas espessas sob alta pressão, sendo, posteriormente, secos pela força gravitacional de uma centrífuga. ${ }^{10}$

A secagem consiste na remoção do líquido (solventes orgânicos ou água) a partir de cristais úmidos ou a partir de sólidos ou de células isoladas. Existem vários métodos de secagem e a adoção dependerá de fatores como natureza física do produto acabado, sensibilidade ao calor, forma de aceitação pelo consumidor e custo do produto acabado. A secagem pode ser por remoção da umidade na fase líquida, a qual envolve a secagem pelo calor, como, por exemplo, secagem por atomização, secagem em estufa a vácuo ou em secadores cilíndricos, ou por remoção de umidade na fase sólida, na qual o material é congelado antes do processo, e, com vácuo, a água passa do estado sólido para o estado de vapor, como por exemplo, a liofilização, sendo útil para a secagem de produtos termolábeis, como enzimas, bactérias e antibióticos. ${ }^{10}$

Segundo Kasper e Friess, ${ }^{17}$ a liofilização é um importante e bem-estabelecido processo para aumentar a estabilidade de drogas lábeis, especialmente proteínas terapêuticas. Cerca de $50 \%$ dos 
biofármacos atualmente comercializados são liofilizados, embora a liofilização seja o processo de secagem que consuma mais tempo e energia.

\subsection{ESTERILIZAÇÃO}

A produção de medicamentos estéreis como os biofarmacêuticos requerem utilidades com controle de contaminação e tecnologia de salas limpas. As autoridades regulatórias exigem que todos os produtos biofarmacêuticos sejam produzidos de acordo com os guias de Boas Práticas de Fabricação (BPF) vigentes. ${ }^{11}$

De acordo com Okafor, ${ }^{10}$ contaminações em indústrias biotecnológicas podem causar grandes perdas financeiras. O contaminante pode utilizar componentes do caldo de fermentação para produzir produtos indesejáveis, pode alterar as condições de $\mathrm{pH}$ ou potencial de oxidação-redução do meio, pode destruir o micro-organismo produtor ou produzir subprodutos de difícil remoção do produto de interesse.

Para atingir a esterilidade, existem vários métodos físicos e químicos. São métodos físicos de esterilização: assepsia, filtração, aquecimento - por calor seco e por calor úmido, tindalização, pasteurização, vapor sob pressão reduzida e vapor úmido, ou radiação (ionizante e luz ultravioleta). Os métodos químicos consistem em esterilizantes químicos e desinfetantes, óxido de etileno, formaldeído e outros. ${ }^{10}$

\subsection{CONTROLE DE PROCESSO}

A fase de crescimento em processos de fermentação pode ser guiada por instrumentos analíticos com sensores de oxigênio dissolvido e de $\mathrm{pH}{ }^{18,19}$

No entanto, a aplicação de tecnologias de separação acopladas à espectrometria de massas (CLAE-MS) e espectrometria de ressonância magnética nuclear (RMN) em processos biotecnológicos pode apresentar maior aplicação do que sensores específicos. Com a combinação de separação por cromatografia de alta eficiência (CLAE) com a alta sensibilidade da espectrometria de massas, é possível investigar a influência de parâmetros de reação em bioprocessos e realizar análises em tempo real por meio da injeção direta de amostras no espectrômetro de massas. ${ }^{18}$

\subsection{ESCALONAMENTO E AUTOMATIZAÇÃO}

Problemas relacionados a equipamentos nos escalonamentos ocorrem em razão da interface inadequada de transferência de massa e calor, bem como das concentrações e perfil de temperatura não uniformes. A transferência insuficiente de oxigênio para as células também é um dos problemas nos escalonamentos de fermentações submersas, limitando as taxas de crescimento. ${ }^{11}$ 
Um exemplo, o Plasmídeo de DNA para aplicações biofarmacêuticas é produzido principalmente em células de E. coli, e a recuperação do plasmídeo é feita por meio do rompimento celular alcalino, seguido de neutralização e clarificação. Inicialmente, foi desenvolvido em escala piloto um sistema automatizado e contínuo para realizar o processo de lise e clarificação, o qual é possível ser escalonado. ${ }^{20}$

\section{CONCLUSÃO}

Considerando-se a grande complexidade da genética humana, dos micro-organismos, a produção de medicamentos biológicos ou derivados de processos biotecnológicos que garantam tratamento contra doenças demanda uma série de conhecimentos, entre eles conhecimentos de engenharia genética e dos processos químicos. Assim, os biofármacos e, consequentemente, as formas biofarmacêuticas estão entre os blockbusters da indústria farmacêutica, tamanha a importância econômica e estratégica destes. Dessa forma, entender todas as etapas do processo produtivo em escala industrial, desde a recombinação de DNAs das células hospedeiras até a purificação e o isolamento do biofármaco, bem como o desenvolvimento do biomedicamento, é de suma importância para se acompanhar o avanço tecnológico provocado pela biotecnologia e, assim, conseguir medicamentos que permitam o tratamento efetivo com efeitos colaterais reduzidos para doenças crônicas.

\section{REFERÊNCIAS}

1. Bunnage ME. Getting Pharmaceutical R\&D Back on Target. Nature Chemical Biology. Nature Publishing Group. 2011 Jun; 7(6):335-339.

2. Roche. Medicamentos Biológicos. [acesso em 2013 maio 09]. Disponível em: http://www.roche.com.br/fmfiles/re7193008/pdf/medicamentosbiologicos1.pdf

3. Ferro ES. Biotecnologia translacional: hemopressina e outros peptídeos intracelulares. Estudos Avançados. 2010; 24(70):109-121.

4. Almeida H, Amaral MH, Lobão P. Drugs obtained by biotechnology processing. Brazilian Journal of Pharmaceutical Sciences. 2011 Apr-Jun; 47(2):199-207.

5. Karg SR, Kallio PT. The production of biopharmaceuticals in plant systems. Biotechnology Advances. 2009; (27):879-894.

6. Martinez JL, Liu L, Petranovic D, Nielsen J. Pharmaceutical protein production by yeast: towards production of human blood proteins by microbial fermentation. Current Opinion in Biotechnology. 2012; (23):965-971.

7. Houdebine LM. Production of pharmaceutical proteins by transgenic animals. Comparative Immunology, Microbiology and Infectious Diseases. 2009; 32:107-121. 
8. Fischer R, Schillberg S, Hellwig S, Twyman RM, Drossard J. GMP issues for recombinant plantderived pharmaceutical proteins. Biotechnology Advances. 2012; (30):434-439.

9. Yilmaz E. Biotechnological production of prostaglandin. Biotechnology Advances. 2001; (19):387397.

10. Okafor N. Modern Industrial Microbiology and Biotechnology. 1a. ed. Enfield, New Hampshire: Science Publishers; 2007.

11. Närhi M, Nordström K. Manufacturing, regulatory and commercial challenges of biopharmaceuticals production: a Finnish perspective. European Journal of Pharmaceutics and Biopharmaceutics. 2005; (59):397-405.

12. Luvielmo MM, Scamparini ARP. Goma xantana: produção, recuperação, propriedades e aplicação. Estudos tecnológicos. 2009 jan-abr; 5(1):50-67.

13. Fumagali E, Gonçalves RAC, Machado MFPS, Vidoti GJ, Oliveira, AJB. Produção de metabólitos secundários em cultura de células e tecidos de planta: o exemplo dos gêneros Tabernaenmontana e Aspidosperma. Rev Bras Farm. 2008 out-dez; 18(4):627-641.

14. Sutherland K. Pharmaceuticals: Filtration plays key role in pharmaceuticals and biotechnology. Filtration \& Separation. 2011 Mar-Apr; 16-19.

15. Kragl U. Technology Transfer in Biotechnology: From Lab to Industry to Production. In: Scheper T. Advances in Biochemical Engineering/Biotechnology. 2005; 92:1-48.

16. Gottschalk U. Downstream Processing. In: Jornitz MW, Meltzer TH. Filtration and Purification in the Biopharmaceutical Industry. 2a. ed. New York: Informa Healthcare USA; 2008.

17. Kasper JC, Friess W. The freezing step in lyophilization: Physico-chemical Fundamentals, freezing methods and consequences on process performance and quality attributes of biopharmaceuticals. Eur. Jour. of Pharm. and Biopharm. 2011; (78):248-263.

18. Wohlgemuth R. The locks and Keys to industrial biotechnology. New Biotechnology. 2009 Apr; 25(4):204-214.

19. Behr A, Brehme VA, Ewers CLJ, Grön H, Kimmel T, Küppers S, et al. New Developments in Chemical Engineering for the Production of Drug Substances. Engineering Life Science. 2004; 4(1):15-24.

20. Urthaler J, Ascher C, Wöhrer H, Necina R. Automated alkaline lysis for industrial scale cGMP production of pharmaceutical grade plasmid-DNA. Journal of Biotechnology. 2007; (128):132-149. 
